\title{
Dysregulation of the Glutamine Transporter Slc38a3 (SNAT3) and Ammoniagenic Enzymes in Obese, Glucose-Intolerant Mice
}

\author{
Stephanie M. Busque Gerti Stange Carsten A. Wagner \\ Institute of Physiology, Zurich Center for Integrative Human Physiology ZIHP, University of Zurich, \\ Zurich, Switzerland
}

\author{
Key Words \\ Ammoniagenesis • Proximal tubule • Obesity $\bullet$ Glutamine transport
}

\begin{abstract}
Background/Aims: Uric acid nephrolithiasis is prevalent among patients with type 2 diabetes and metabolic syndrome; it is correlated with an acidic urine and lower urinary ammonium excretion and is likely associated with insulin resistance. Insulin stimulates ammoniagenesis in renal cell lines via increased phosphate-dependent glutaminase (PDG) activity and glutamine metabolism. Ammonium excretion into the proximal tubule is mediated at least in part by the $\mathrm{Na}^{+} / \mathrm{H}^{+}$-exchanger NHE3 and in the collecting duct involving the Rhesus protein RhCG. Here we tested, whether obesity and insulin resistance in a diet-induced mouse model could contribute to deranged ammonium excretion. Methods: Obesity was induced by diet in mice and the impact on key molecules of proximal tubular ammoniagenesis and urinary acid excretion tested. Results: Diet-induced obesity was confirmed by pathological intraperitoneal glucose tolerance tests (IPGTT). Three groups of mice were compared: control mice; obese, glucose-intolerant with abnormal IPGTT (O-GI); or moderate weight with normal IPGTT (NonResponders, NR). Basal urinary ammonium excretion did not differ among groups. However, acid loading increased urinary ammonium excretion in all groups, but to a lesser extent in the O-GI group. SNAT3 mRNA expression was enhanced in both obese groups. PDG expression was elevated only in acid-loaded O-GI mice, whereas PEPCK was enhanced in both O-GI and $\mathrm{NR}$ groups given $\mathrm{NH}_{4} \mathrm{Cl}$. NHE activity in the brush border membrane of the proximal tubule was strongly reduced in the O-GI group whereas RhCG expression was similar. Conclusion: In sum, obesity and glucose intolerance impairs renal ammonium excretion in response to $\mathrm{NH}_{4} \mathrm{Cl}$ feeding most likely through reduced NHE activity. The stimulation of SNAT3 and ammoniagenic enzyme expression may be compensatory but futile.
\end{abstract}




\section{Cellular Physiology and Biochemistry}

Cell Physiol Biochem 2014;34:575-589

\begin{tabular}{l|l}
\hline DOI: $10.1159 / 000363024$ & (c) 2014 S. Karger AG, Basel
\end{tabular}

www.karger.com/cpb

Busque/Stange/Wagner: Obesity and Dysregulation of SNAT3

\section{Introduction}

The prevalence of diabetes from a global perspective has reached approximately 170 million and is expected to rise further [1]. Interestingly, the incidence of nephrolithiasis in this population has increased in parallel, and it has been suggested that a relationship may exist between these metabolic disorders and renal stone formation [2-4]. A recent cross-sectional analysis comparing three large epidemiological studies over a 44 year period found that diabetes appeared to be a significant risk factor for developing uric acid nephrolithiasis (UAN), and had suggested that insulin resistance could be the effecter [5]. UAN is highly associated with low urinary $\mathrm{pH}$ and urine volume, hyper- or normouricosuria, and the increased incidence of diabetes or insulin resistance [6-10]. Pharmacological treatment with potassium or sodium citrate has been proven to increase urinary $\mathrm{pH}$ and inhibit UA stone formation, providing further evidence that UAN is linked to low urinary $\mathrm{pH}$ $[11,12-14]$. Patients with diabetes and UAN not only have low urinary $\mathrm{pH}$ values, but also exhibit decreased renal ammonium excretion. The mechanism likely involves defective renal ammoniagenesis or excretion since a low urinary $\mathrm{pH}$ usually is associated with enhanced ammonium excretion in the urine [7, 11, 15-18]. Furthermore, functional acid-loading tests in these patients resulted in a reduced capacity to acidify their urine in comparison to healthy controls [7].

Renal ammoniagenesis and gluconeogenesis increase substantially in the proximal tubule (PT) in response to acute or chronic metabolic acidosis. This is a direct result of the shunting of glutamine from the visceral or splanchnic pool to the kidney, with concomitant increases in glutamine extraction from blood $[19,20]$. We and others have shown that glutamine influx is likely due to the basolateral proximal tubule glutamine transporter Slc38a3 (SNAT3), since increased SNAT3 expression has been observed during metabolic acidosis [21-25]. SNAT3 (Slc38a3) mediates the transport of glutamine while $\mathrm{Na}^{+}$and $\mathrm{H}^{+}$ ions are exchanged [26]. Recent work by our group has also shown enhanced SNAT3 mRNA and protein in response to potassium restriction or a high protein diet, conditions that create an acidosis-like state and stimulate renal ammoniagenesis [27-34]. Glutamine is then transported into the mitochondria of the PT cell and metabolized. One ammonium ion is liberated through the deamidation of glutamine to glutamate via phosphate-dependent glutaminase (PDG), while another ammonium ion is produced upon conversion of glutamate to $\alpha$-ketoglutarate. In the PT cell cytosol, $\alpha$-ketoglutarate has two metabolic fates; as a substrate in the tricarboxylic acid cycle, or as a precursor of de novo glucose synthesis in the presence of phosphoenolpyruvate carboxykinase (PEPCK), resulting in the production of two bicarbonate molecules. Increases in PDG and PEPCK enzyme activity during metabolic acidosis have been associated with a concomitant increase in mRNA levels and protein abundance and are thus important regulators of ammoniagenesis [35-39]. These two enzymes are, however, differentially regulated. PDG is augmented during MA as a result of increased stabilization of its mRNA secondary to the binding of $\xi$-crystallin/NADPH:quinone reductase to a $\mathrm{pH}$ responsive AU-rich region in the 3' untranslated region of its $\mathrm{mRNA}$, while increases in PEPCK are mostly the result of augmented transcription of the PEPCK gene [39].

Once ammonium is produced in the PT, it is transported into the tubular lumen. This is accomplished either via diffusion as $\mathrm{NH}_{3}$ where it can trap protons, or it can be transported as ammonium. A key protein involved in the luminal transport of ammonium as well as providing protons for bicarbonate reabsorption is the $\mathrm{Na}^{+} / \mathrm{H}^{+}$exchanger, NHE3, localized to the brush border membrane of the PT and increased during $\mathrm{NH}_{4} \mathrm{Cl}$-induced $\mathrm{MA}$ [40-42]. Reabsorption of ammonium produced by the PT occurs in the medullary thick ascending limb largely by the activation of a luminal $\mathrm{Na}^{+} / \mathrm{K}^{+} / 2 \mathrm{Cl}^{-}$cotransporter (NKCC2) [43]. After accumulation in the medullary interstitium, a process dependent on sulfatides, ammonium is ultimately excreted in the final urine, via the Rhesus factor Rhcg protein [44-47].

The ammoniagenic pathway is also regulated by several hormones: angiotensin II and insulin stimulate ammoniagenesis whereas prostaglandin PGF2 $\alpha$ reduces it [4850]. The renal proximal tubule is also an important gluconeogenic site and in contrast to 


\section{Cellular Physiology and Biochemistry}

Cell Physiol Biochem 2014;34:575-589

DOI: 10.1159/000363024

Publisned onirne: August 11, 2014

Busque/Stange/Wagner: Obesity and Dysregulation of SNAT3
(C) 2014 S. Karger AG, Basel

www.karger.com/cpb

ammoniagenesis gluconeogenesis is reduced by insulin [51-55]. Induction of diabetes in rats in vivo or in renal cortex slices results in increased gluconeogenesis, while supplying insulin results in a substantial decrease in gluconeogenic activity [56-58]. Further, insulin can also stimulate NHE3 activity in the proximal tubule [59-62]. A recent study has shown that Zucker diabetic fatty rats with a mutation in the leptin receptor gene exhibit reduced urinary ammonium and $\mathrm{pH}$, with a concomitant reduction in renal brush border membrane NHE3 activity, suggesting that renal ammonium excretion is reduced in part by a reduction in NHE3 activity [63].

Given that both ammoniagenesis and gluconeogenesis are closely linked in the renal proximal tubule cell, we hypothesized that a diet-induced, glucose-intolerant state could alter renal ammoniagenesis through dysregulation of the glutamine transporter SNAT3, renal ammoniagenic and gluconeogenic enzymes, PDG and PEPCK, or transport proteins involved in renal ammonium excretion. Modifications in the regulation of these proteins could ultimately result in perturbations in ammoniagenesis and excretion, and could help to explain the pathogenesis of UAN in subjects with diabetes and metabolic syndrome.

\section{Material and Methods}

\section{Animals}

Male C57BL6 mice ( $\mathrm{n}=72$ ) were randomly assigned to two different dietary treatment groups and placed on either a standard diet (control, $n=24$ ) or "cafeteria" style diet $(n=48)$ for 10 weeks. A cafeteria style diet consists of various combinations of energy dense foodstuffs, and is widely used as a model for diet-induced obesity [64]. Our experimental cafeteria diet consisted of unsalted ground peanuts (40\%), cookies (25\%) and chocolate (15\%) mixed with standard rodent chow (20\%) to ensure adequate macroand micronutrient composition. The nutrient composition of the cafeteria diet was as follows: $460 \mathrm{kcal}, 15$ $\mathrm{g}$ of protein, $25 \mathrm{~g}$ of carbohydrate and $34 \mathrm{~g}$ of fat per $100 \mathrm{~g}$ of ground food. Mice had ad libitum access to food and water during the 10 week dietary treatment period, and were housed in climate controlled and 12 $\mathrm{h}$ light-cycled rooms. All mice were weighed weekly. Animal experiments were conducted according to the Swiss animal welfare laws and approved by the Swiss local animal authority, Zurich, Switzerland.

\section{Intraperitoneal glucose tolerance tests (IPGTT)}

After 10 weeks of dietary treatment, each mouse was subjected to IPGTT. The test was performed over a $2 \mathrm{~h}$ period. Mice were fasted overnight with free access to water. A single dose of glucose $(2 \mathrm{mg} / \mathrm{g}$ body weight) was given upon initiation of testing, followed by blood collections from the tail vein every 30 minutes. Glucose monitoring was performed using the Accu-chek blood glucose meter (Roche). After the IPGTT, mice were divided into various groups depending on the test outcome: control with normal IPGTT; Obese, Glucose-Intolerant mice with abnormal IPGTT (subsequently named: O-GI); or moderately obese with relatively normal IPGTT (Non-Responders, NR). All mice were allowed to recover from the IPGTT for one week, and were subsequently housed in metabolic cages for the next series of experiments.

\section{Metabolic cage studies}

Mice were individually placed in metabolic cages for a total of 4 days, and continued on the experimental diets. Control, O-GI and NR mice were subdivided into $\mathrm{NH}_{4} \mathrm{Cl}$ treated groups; $\mathrm{NH}_{4} \mathrm{Cl}$ was powdered into the food $(2 \mathrm{~g} / 100 \mathrm{~g}$ chow) for the final $48 \mathrm{~h}$. Food and water intake, body weight and urinary output were monitored daily. During the final $48 \mathrm{~h}$ of dietary treatment, urine was collected every 24 hours under mineral oil and urinary $\mathrm{pH}$ was immediately assessed using a pH microelectrode (691 $\mathrm{pH}$ meter, Metroholm). The Berthelot and Jaffe methods were used to assess urinary $\mathrm{NH}_{3} / \mathrm{NH}_{4}{ }^{+}$and creatinine concentration $[65,66]$. At the end of the experimental treatment, mice were anesthetized by intraperitoneal injection of ketamine and xylazine, and blood was collected in heparinized tubes, immediately centrifuged to extract plasma, and frozen at $-80^{\circ} \mathrm{C}$. Mice were not perfused prior to harvesting kidneys given that neither SNAT3, nor PDG and PEPCK are expressed in whole blood or erythrocytes, respectively [67]. Although there is some evidence suggesting white blood cells exhibit PDG activity, exsanguination caused by the blood collections minimized the likelihood of blood cell contamination in our preparations [68]. Kidneys were harvested, flash-frozen in liquid nitrogen, and transferred to a $-80^{\circ} \mathrm{C}$ freezer until further use. 


\section{Cellular Physiology and Biochemistry}

Cell Physiol Biochem 2014;34:575-589

DOI: $10.1159 / 000363024$

Published onIIne: August 11, 2014

2014 S. Karger AG, Basel

www.karger.com/cpb

Semi-quantitative Real-time RT PCR

Previously frozen kidneys were homogenized using a Rotor-stator homogenizer, and RNA was immediately extracted using Qiagen RNeasy Mini Kit (Qiagen; Hilden, Germany). DNase digestion was performed using the RNase-free DNase Set (Qiagen; Hilden, Germany). Total RNA extractions were analyzed using the NanoDrop ND-1000 spectrophotometer (Wilmington, DE, USA). cDNA was prepared from diluted RNA samples (100 ng/ $\mu \mathrm{l}$ ) using the TaqMan Reverse Transcriptase Reagent Kit containing 10X RT buffer, $\mathrm{MgCl}_{2}$, random hexamers, dNTPs, RNase inhibitors and Multiscribe reverse transcription enzyme (Applied Biosystems/Roche; Forster City, CA, USA). Thermocycling conditions for reverse transcription were set at $25^{\circ} \mathrm{C}$ for $10 \mathrm{~min}, 48^{\circ} \mathrm{C}$ for $30 \mathrm{~min}$, and $95^{\circ} \mathrm{C}$ for $5 \mathrm{~min}$ (Biometra TGradient thermocycler, Goettingen, Germany). Semi-quantitative Real-time RT-PCR was used to determine relative mRNA expression (7500 Fast Real-Time PCR system, Applied Biosystems). Thermocycling conditions were set at: $50 \stackrel{\circ}{\circ} \mathrm{C}(2 \mathrm{~min}), 95^{\circ} \mathrm{C}$ (10 min), $95^{\circ} \mathrm{C}(15 \mathrm{sec} ; 40$ cycles $)$ and $60^{\circ} \mathrm{C}(1 \mathrm{~min})$. Forward and reverse primer concentration was 25 $\mu \mathrm{M}$; probe concentration was $5 \mu \mathrm{M}$. TaqMan Universal PCR master mix 2X (Applied Biosystems/Roche) was used as the Taq polymerase. Primers and probes for SNAT3, phosphate dependent glutaminase (PDG), phosphoenolpyruvate carboxykinase (PEPCK), rhesus glycoprotein (Rhcg) and Hypoxanthine-guanine phosphoribosyltransferase (HPRT) were generated using the Primer Express software from Applied Biosystems and synthesized at Microsynth (Balgach, Switzerland) as described previously [25]. The primer and probe sequences for Rhcg were 5'-GTT GGA GAA GAA GCG CAA GAA-3', forward; 5'-CGA AGA CCA TGG CGT GTA CA-3', reverse; 5'-TTA CTA TCG CTA CCC GAG CTT CCA G-3', probe. Probes were generated with the reporter dye FAM at the 5' end and TAMRA at the 3' end. Each sample was run in triplicate including a negative control (without Multiscribe reverse transcription enzyme). The cycle threshold $\left(C_{t}\right)$ values obtained were ultimately compared to $C_{t}$ values of the endogenous gene HPRT. Relative mRNA expression ratios were calculated as $\mathrm{R}=2^{[\mathrm{Ct}(\mathrm{HPRT})-\mathrm{Ct}(\text { gene of interest })]}$.

\section{Immunoblotting}

Total membrane and cytosolic protein preparations were prepared from whole, non-perfused kidneys using a K-HEPES buffer composed of $200 \mathrm{mM}$ mannitol, $80 \mathrm{mM} \mathrm{HEPES,} 41 \mathrm{mM} \mathrm{KOH}$, along with the protease inhibitors, PMSF, K-EDTA, and leupeptin (pH 7.5). Kidneys were homogenized in $200 \mu$ l of ice-cold K-HEPES buffer using a tip sonicator and immediately centrifuged at $2000 \mathrm{rpm}$ for $20 \mathrm{~min}\left(4^{\circ} \mathrm{C}\right)$. The supernatant was aspirated and placed in an ultracentrifuge (Sorvall, Thermo Fischer Scientific) for $1 \mathrm{~h}$ at $41,000 \mathrm{rpm} 4^{\circ} \mathrm{C}$. The supernatant containing cytosolic protein from this second centrifugation step was removed and the pellet containing membrane protein was resuspended in K-HEPES buffer and sonicated to evenly distribute proteins. The BioRad Dc Protein assay was used to measure protein concentration (Bio-Rad; Hercules, CA, USA). Total membrane $(75 \mu \mathrm{g})$ or cytosolic $(50 \mu \mathrm{g})$ protein containing Laemmli sample buffer and loaded onto a $10 \%$ polyacrylamide gel and SDS-PAGE was performed. Proteins were transferred to polyvinylidene difluoride membranes (PVDF; Immobilon-P, Millipore, Bedford, MA, USA). Membranes were blocked with Tris-buffered saline / $0.1 \%$ Tween and 5\% non-fat dry milk for $1 \mathrm{~h}$. Primary antibodies were applied for $2 \mathrm{~h}$ at RT or overnight at $4^{\circ} \mathrm{C}$. The primary antibodies used for this study were: phosphate-dependent glutaminase (PDG), which recognizes both the rat (KGA) and human (GAC) kidney-type isoforms of PDG forming the mature PDG protein $(66$ and $68 \mathrm{kDa}$; a kind gift from N. Curthoys, Colorado State University, USA; diluted 1:500) [69]; anti-PEPCK polyclonal antibody (63 kDa; Cayman Chemical, Ann Arbor, MI, USA; diluted 1:1,000), and mouse monoclonal antibody against $\beta$-actin (42 kDa; Sigma, St. Louis, MO, USA; diluted 1:5,000). The anti-Slc38a3 antibody (1:500) was generated as previously described [24]. The secondary antibodies used were anti-rabbit alkaline phosphatase conjugated diluted 1:5,000, and anti-mouse IgG alkaline phosphatase conjugated diluted 1:5,000 or anti-mouse IgG horseradish peroxidase-conjugated 1:10,000, and donkey anti-rabbit HRP 1:12,000. After a series of washing steps and blocking, membranes were treated with alkaline phosphatase- or horseradish peroxidase-conjugated developing solution (Immobilion, location) and exposed to the Diana III chemiluminescence detection system (Raytest). Specific bands on PVDF membranes were later quantified using AIDA Image analyzer version 3.44. Membranes were stripped and reprobed for anti- $\beta$-actin and subsequent analysis of the protein of interest was determined relative to $\beta$-actin quantification and reported as relative protein abundance (ratio of $\beta$-actin/protein of interest). 


\section{Cellular Physiology and Biochemistry}

Cell Physiol Biochem 2014;34:575-589

DOI: $10.1159 / 000363024$

(C) 2014 S. Karger AG, Basel

www.karger.com/cpb

579

Busque/Stange/Wagner: Obesity and Dysregulation of SNAT3

Table 1. Urine analyses were performed to determine the effect of cafeteria style feeding and $\mathrm{NH}_{4} \mathrm{Cl}$ treatment on urinary parameters. Values are means \pm SE of results from analyses for urinary electrolytes, $\mathrm{PO}_{4}{ }^{3-}$ and $\mathrm{NH}_{4}{ }^{+}$relative to creatinine in mice ( $\mathrm{n}=8$ mice per group) treated with a standard or cafeteria diet for 10 weeks, with or without $\mathrm{NH}_{4} \mathrm{Cl}$ supplementation in the food for the final 2 days. ${ }^{\mathrm{a}} P \leq 0.05$; ${ }^{\mathrm{b}} P \leq 0.01$; ${ }^{\mathrm{c}} P \leq 0.001$, comparisons between control and treated groups. ${ }^{\mathrm{d}} P \leq 0.05$; ${ }^{\mathrm{e}} P \leq 0.01 ;{ }^{\mathrm{f}} P \leq 0.001$, comparisons between cafeteria-fed groups. ${ }^{\mathrm{g}} P \leq 0.05$; ${ }^{\mathrm{h}} P \leq 0.01$; ${ }^{\mathrm{i}} P \leq 0.001$, comparisons between acid-loaded groups

\begin{tabular}{|c|c|c|c|c|c|c|}
\hline Groups & Control & $\begin{array}{l}\mathrm{NH}_{4} \mathrm{Cl} \\
2 \text { days }\end{array}$ & O-GI & $\begin{array}{c}\mathrm{O}-\mathrm{GI} / \mathrm{NH}_{4} \mathrm{Cl} \\
2 \text { days }\end{array}$ & NR & $\begin{array}{c}\mathrm{NR} / \mathrm{NH}_{4} \mathrm{Cl} \\
2 \text { days }\end{array}$ \\
\hline Body wt (g) & $30.7 \pm 0.6$ & $30.1 \pm 1.02$ & $43.8 \pm 1.5^{c}$ & $42.5 \pm 0.7 i$ & $40.1 \pm 1.5^{c}$ & $38.1 \pm 2.5 \mathrm{~g}$ \\
\hline Urine $\mathrm{pH}$ & $6.28 \pm 0.14$ & $5.84 \pm 0.04 \mathrm{~b}$ & $6.38 \pm 0.05$ & $6.01 \pm 0.05 \mathrm{~g}$ & $6.42 \pm 0.21$ & $5.90 \pm 0.06$ \\
\hline Urine output $\mathrm{ml} / \mathrm{g}$ bw & $0.05 \pm 0.01$ & $0.04 \pm 0.01$ & $0.02 \pm 0.003^{a}$ & $0.03 \pm 0.003 \mathrm{~g}$ & $0.03 \pm 0.01$ & $0.03 \pm 0.003$ \\
\hline Creatinine (mg/di) & $0.92 \pm 0.14$ & $0.65 \pm 0.12$ & $0.72 \pm 0.12$ & $0.58 \pm 0.11$ & $0.86 \pm 0.12$ & $0.83 \pm 0.11$ \\
\hline $\mathrm{Na}^{*}(\mathrm{mM}) / \mathrm{crea}(\mathrm{mg} / \mathrm{dl})$ & $1.2 \pm 0.2$ & $1.1 \pm 0.1$ & $1.0 \pm 0.2$ & $0.8 \pm 0.1$ & $1.1 \pm 0.3$ & $0.6 \pm 0.1$ \\
\hline $\mathrm{K}^{+}(\mathrm{mM}) / \operatorname{crea}(\mathrm{mg} / \mathrm{dl})$ & $3.6 \pm 0.5$ & $3.7 \pm 0.5$ & $2.1 \pm 0.3^{b}$ & $1.8 \pm 0.4^{\mathrm{h}}$ & $2.7 \pm 0.5$ & $1.5 \pm 0.2^{\mathrm{d}, \mathrm{h}}$ \\
\hline $\mathrm{Ca}^{2}+(\mathrm{mM}) / \mathrm{crea}(\mathrm{mg} / \mathrm{dl})$ & $0.04 \pm 0.01$ & $0.08 \pm 0.02$ & $0.06 \pm 0.02$ & $0.10 \pm 0.02$ & $0.07 \pm 0.01$ & $0.06 \pm 0.01$ \\
\hline $\mathrm{Mg}^{2+}(\mathrm{mM}) / \mathrm{crea}(\mathrm{mg} / \mathrm{dl})$ & $0.27 \pm 0.04$ & $0.31 \pm 0.04$ & $0.24 \pm 0.06$ & $0.26 \pm 0.05$ & $0.22 \pm 0.05$ & $0.24 \pm 0.05$ \\
\hline $\mathrm{Cl}^{-}(\mathrm{mM}) /$ crea $(\mathrm{mg} / \mathrm{dl})$ & $2.5 \pm 0.4$ & $7.9 \pm 0.7 \mathrm{~b}$ & $1.26 \pm 0.18 \mathrm{a}$ & $5.58 \pm 1.22^{e}$ & $1.24 \pm 0.13 a$ & $5.0 \pm 0.40^{f}$ \\
\hline $\mathrm{PO}_{4}{ }^{3 \cdot} \cdot(\mathrm{mM}) /$ crea $(\mathrm{mg} / \mathrm{dl})$ & $0.78 \pm 0.11$ & $0.97 \pm 0.13$ & $0.96 \pm 0.15$ & $1.08 \pm 0.26$ & $1.10 \pm 0.07$ & $1.14 \pm 0.22$ \\
\hline $\mathrm{PO}_{4}^{3 *}, \mathrm{mmol} / 24 \mathrm{~h}$ & $0.094 \pm 0.013$ & $0.092 \pm 0.015$ & $0.057 \pm 0.088^{a}$ & $0.067 \pm 0.007$ & $0.085 \pm 0.014$ & $0.065 \pm 0.004$ \\
\hline $\mathrm{SO}_{4}^{2 \cdot}(\mathrm{mM}) /$ crea $(\mathrm{mg} / \mathrm{dl})$ & $0.52 \pm 0.11$ & $0.57 \pm 0.05$ & $0.33 \pm 0.05$ & $0.36 \pm 0.09 \mathrm{~g}$ & $0.35 \pm 0.05$ & $0.25 \pm 0.03^{\mathrm{h}}$ \\
\hline $\mathrm{NH}_{4}+/$ creatinine $\mathrm{mmol} \cdot \mathrm{mg}^{-1} \cdot \mathrm{dl}$ & $0.595 \pm 0.238$ & $6.21 \pm 1.12^{c}$ & $0.691 \pm 0.107$ & $4.591 \pm 0.722^{f}$ & $2.085 \pm 0.755$ & $6.886 \pm 0.745 \mathrm{fg}$ \\
\hline $\mathrm{NH}_{4}+\mathrm{mmol} / 24 \mathrm{~h}$ & $0.095 \pm 0.045$ & $0.577 \pm 0.114^{b}$ & $0.041 \pm 0.009$ & $0.312 \pm 0.03^{\mathrm{fgg}}$ & $0.092 \pm 0.026$ & $0.481 \pm 0.078$ \\
\hline
\end{tabular}

Brush border membrane acridine orange quenching experiments

Renal brush border membrane vesicle preparations (BBMV) were prepared as previously described [70]. Briefly, kidneys were cut into small sections and homogenized using a Polytron homogenizer with a fine rod for 2 minutes in a buffer containing: $300 \mathrm{mM}$ mannitol, $5 \mathrm{mM}$ EGTA and $12 \mathrm{mM}$ Tris-HCl, pH 7.1. A fraction of the homogenates was stored at $-20^{\circ} \mathrm{C}$ for immunoblotting, while $1 \mathrm{M} \mathrm{MgCl}_{2}$ was added to the remaining homogenate and allowed to precipitate on ice for 15 minutes. The sample was then centrifuged at $4500 \mathrm{rpm}$ for 15 minutes. The supernatant was aspirated and centrifuged at $18000 \mathrm{rpm}$ for 30 minutes. The pellet was resuspended in membrane buffer consisting of: $300 \mathrm{mM}$ mannitol, $20 \mathrm{mM}$ HEPES-Tris, pH 7.4. Samples were then centrifuged at $18500 \mathrm{rpm}$ for 30 minutes. Vesicle buffer was added to samples, containing: $280 \mathrm{mM}$ mannitol, $5 \mathrm{mM}$ MES/N-methyl-D-glutamine and $2 \mathrm{mM} \mathrm{MgCl}_{2}$, $\mathrm{pH}$ 5.5. Protein concentration was measured using the BioRad fast method.

Acridine orange quenching measurements were performed as previously described [71]. Measurements were performed in a Shimadzu RF-5000 spectrofluometer equipped with a thermostatized cuvette (kept at $25^{\circ} \mathrm{C}$ ). BBMVs were dissolved in a buffer containing $280 \mathrm{mM}$ mannitol, $5 \mathrm{mM}$ Mes, and $2 \mathrm{mM}$ $\mathrm{MgCl}_{2}$ (adjusted to $\mathrm{pH} 5.5$ with $\mathrm{N}$-methyl-d-glucamine). Acridine orange was excited at $493 \mathrm{~nm}$, and emission was monitored at $530 \mathrm{~nm}$. The cuvette was filled with $2 \mathrm{ml}$ of buffer (240 mM mannitol/20 mM Hepes/2 mM $\mathrm{MgCl}_{2}$, adjusted to $\mathrm{pH} 7.5$ with $\mathrm{N}$-methyl-d-glucamine), containing $6 \mu \mathrm{M}$ acridine orange. The experiment was started by injecting $30 \mu \mathrm{l}$ of BBMV suspension. After $60 \mathrm{~s}$ of equilibration, NHE activity was initiated by injection of $80 \mu \mathrm{l}$ of $2 \mathrm{M}$ Na gluconate. NHE activity was calculated as ratio of $\Delta \mathrm{pH}$ per min over $Q$, where $Q$ is the initial quenching after injection of BBMV. All experiments were done at least in quadruplicates.

Statistical analyses were performed using unpaired Student's $t$-test, and results with $\mathrm{p}<0.05$ were considered statistically significant. Data are reported as means \pm SEM.

\section{Results}

"Cafeteria-diet" feeding induces obesity and pathological glucose intolerance in mice After 10 weeks of a high fat, high energy "cafeteria-style diet", or a standard control diet, all mice $(n=72)$ were subjected to intraperitoneal glucose tolerance testing (IPGTT). Control mice had the lowest body weight (31.3 $\pm 0.6 \mathrm{~g}$ ) and showed no evidence for glucose intolerance (Fig. 1, Table 1). IPGTT revealed two distinct tiers of glucose intolerance among the cafeteriafed mice. Approximately half of the cafeteria-fed mice were significantly obese $(43.5 \pm 0.9$ g) and did not reach euglycemia at the end of the IPGTT (Obese, Glucose-Intolerant; 0-GI group), while the other half of cafeteria-fed mice were moderately obese (37.8 $\pm 1.4 \mathrm{~g})$ and clearly less glucose intolerant (Non-Responders; NR group). A similar phenomenon has been described in rats showing that chronic consumption of a high fat, high calorie diet led 
Fig. 1. Two tiers of glucose intolerance are unmasked in cafeteria-fed mice after intraperitoneal glucose tolerance testing. Intraperitoneal glucose tolerance tests were performed on all mice $(n=72)$ after 10 weeks of a standard or cafeteria diet. Mice were fasted overnight and blood glucose monitoring was performed every 30 minutes for $2 \mathrm{~h}$ after an initial glucose injection $(2 \mathrm{mg} / \mathrm{g}$ body weight). The most severely glucose-intolerant mice were subsequently named Obese, glucose-intolerant (O-GI), while the second tier of mice had moderately elevated blood glucose levels and were called the Non-responders (NR).

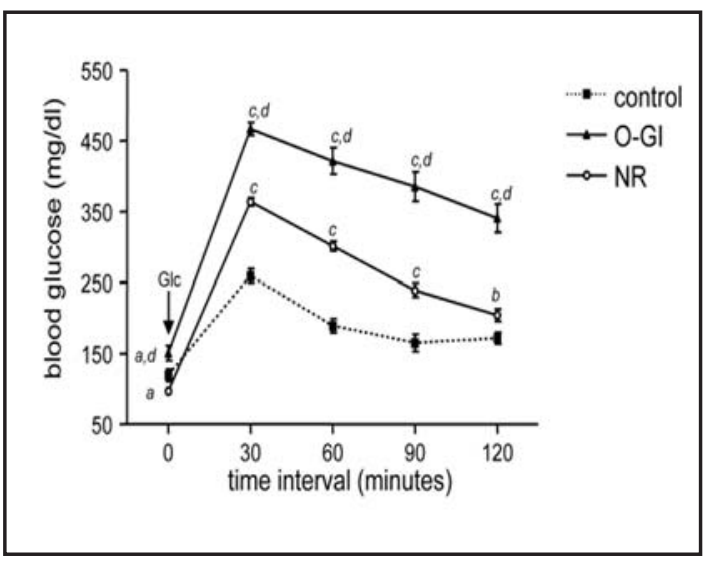

Fig. 2. Acid challenging cafeteria-fed mice with $\mathrm{NH}_{4} \mathrm{Cl}$ reveals a difference in ammonium excretion and urinary acidification in $\mathrm{O}$-GI mice. Mice were placed in metabolic cages and urine was collected for the final two consecutive $24 \mathrm{~h}$ intervals under mineral oil. (A) All acid-loaded groups exhibited low urinary $\mathrm{pH}$ values in comparison to respective controls, however O-GI mice showed a slightly more alkaline urine than $\mathrm{NH}_{4}$ Cl-loaded mice fed a standard diet. (B) $24 \mathrm{~h}$ urinary ammonium excretion relative to creatinine was significantly reduced in $\mathrm{O}-\mathrm{GI}$, but not NR mice. ${ }^{*} p<0.05$, ${ }^{* *} p<0.01,{ }^{* * *} p<0.001$, $\mathrm{n}=6$ mice/group.

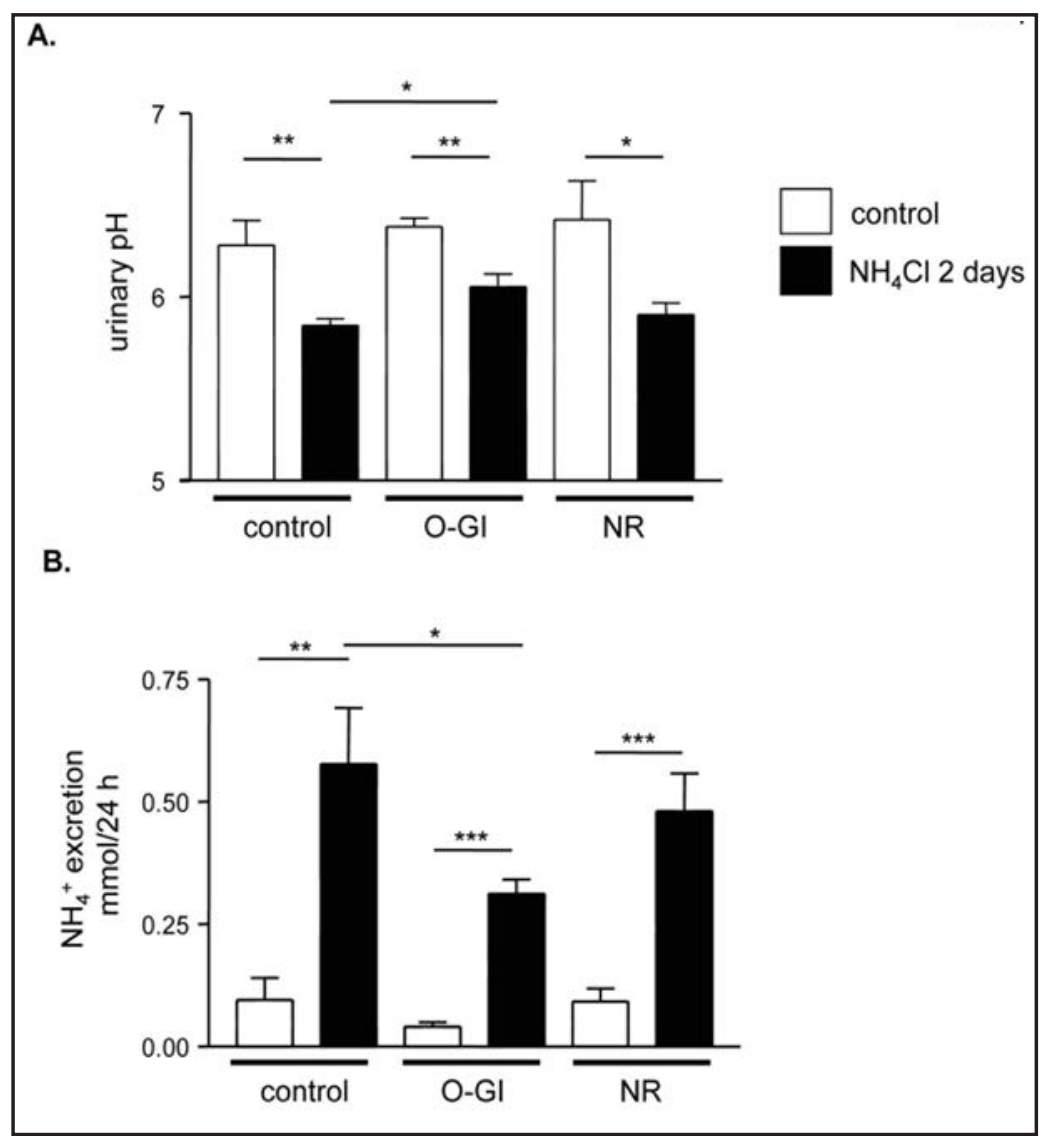

to a weight differential in roughly half of the study population tested, resulting in obesity and insulin resistance [72-74]. Furthermore, these observations were noted without a further increase in food intake in these animals, which has been suggested to be associated with irreversible changes in body weight and adiposity set-points.

\section{Abnormal urinary acid excretion in obese, glucose-intolerant mice}

Mice from all three groups $(n=48)$ were placed in metabolic cages after one week of recovery from IPGTT and maintained on their respective diets. The O-GI, NR and control groups were subdivided and challenged with an acid load consisting of $\mathrm{NH}_{4} \mathrm{Cl}$ powdered into

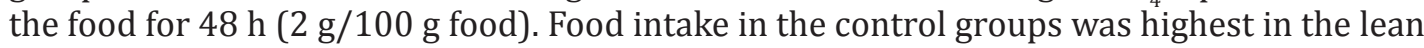




\section{Cellular Physiology and Biochemistry}

Cell Physiol Biochem 2014;34:575-589

Fig. 3. O-GI mice show strong upregulation of SNAT3 mRNA and protein abundance after an acid challenge with $\mathrm{NH}_{4}$ Cl. mRNA expression of SNAT3 was determined in kidneys using semi-quantitative real-time RT PCR in mice fed a standard or cafeteria diet for 10 weeks with or without $\mathrm{NH}_{4} \mathrm{Cl}$ supplementation in food, and normalized against HPRT mRNA expression. All acidloaded groups showed enhanced SNAT3 mRNA expression, with the O-GI group showing the highest upregulation of SNAT3 (A). (B-K) Immunoblotting for SNAT3 in total membranes. All blots were stripped and reprobed for $\beta$-actin to control for equal loading. Original blots are depicted with bar graphs s u m m ari zing normalized data. ${ }^{*} p<0.05,{ }^{* *} p<0.01$, and ${ }^{* * *} p<0.001$ between groups, $\mathrm{n}=5$ mice/ group.

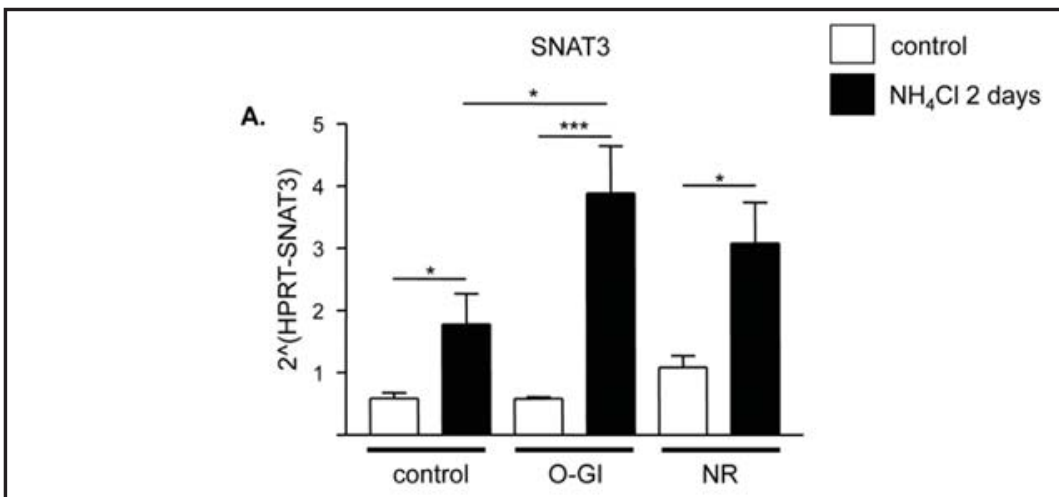

B.
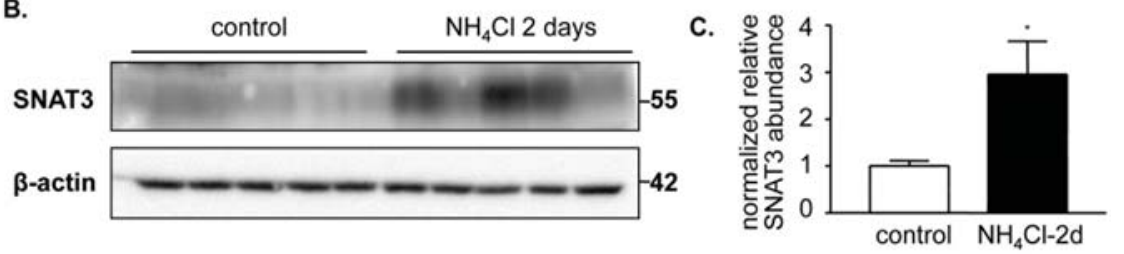

D.
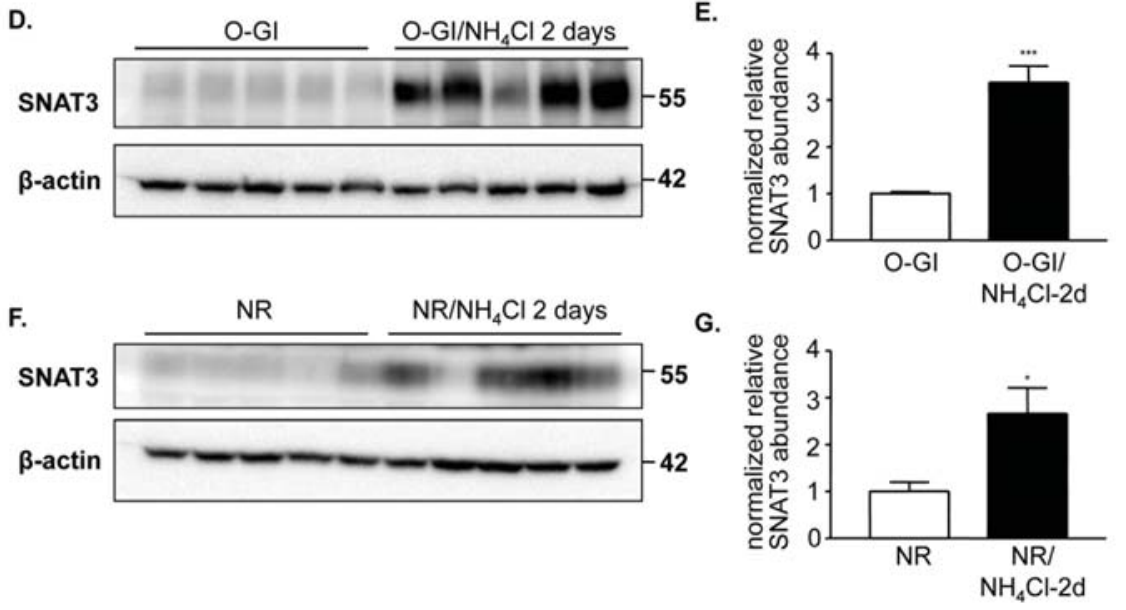

H.

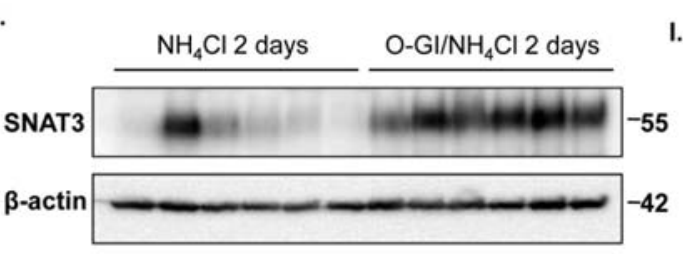

J.
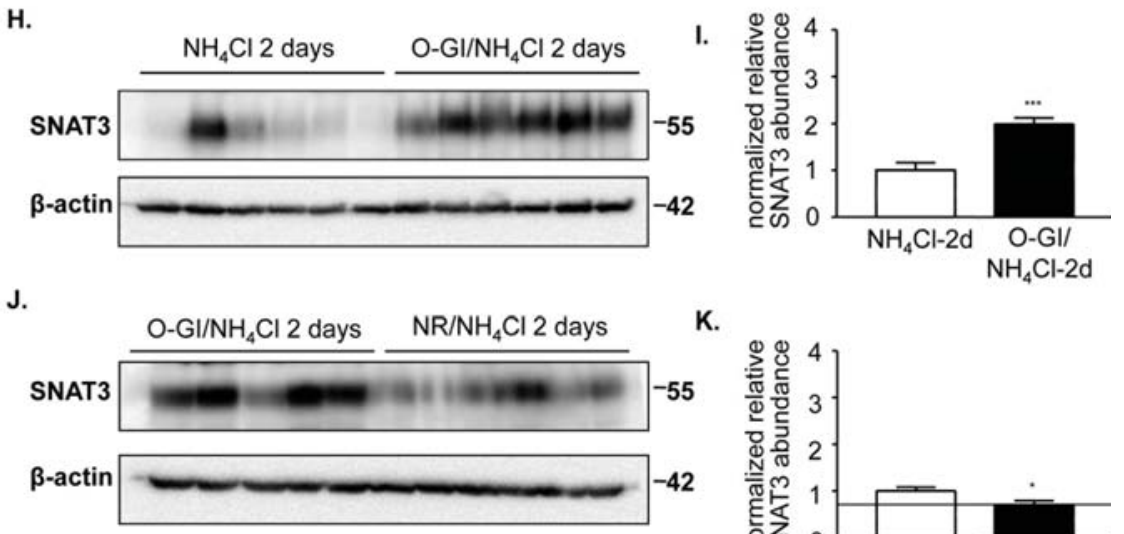

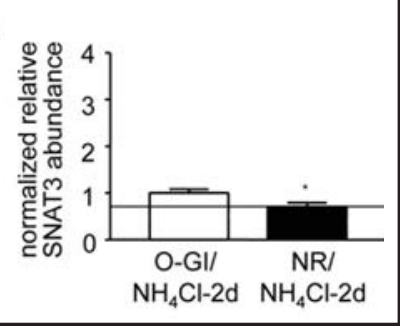

mice and similar between the O-GI and NR groups (control: $3.55 \pm 0.16 \mathrm{~g} /$ day; O-GI: $2.02 \pm$ $0.09 \mathrm{~g}$ /day; $\mathrm{NR}: 2.13 \pm 0.11 \mathrm{~g}$ /day). $\mathrm{NH}_{4} \mathrm{Cl}$ addition reduced daily food intake in all groups but remained higher in the lean mice and was not significantly different between the two obese groups (control: $2.71 \pm 0.21 \mathrm{~g} /$ day; 0 -GI: $1.27 \pm 0.13 \mathrm{~g} /$ day; NR: $1.65 \pm 0.08 \mathrm{~g} /$ day). 
Fig. 4. Phosphate-dependent glutaminase is strongly enhanced in O-GI mice after an acidload. mRNA expression of PDG was determined using semi-quantitative real-time RT PCR. PDG mRNA was enhanced in all groups after an acid load, and most strongly in the O-GI group given $\mathrm{NH}_{4} \mathrm{Cl}$ when compared to acid-loaded control and NR mice (A). (BG) Cytosolic proteins were extracted from whole, non-perfused kidneys and probed for PDG. All blots were stripped and reprobed for $\beta$-actin to control for equal loading. Original blots are depicted with bar graphs summarizing normalized data. ${ }^{*} p<0.05$, ** $p<0.01$ between groups, $\mathrm{n}=5$ mice/ group.

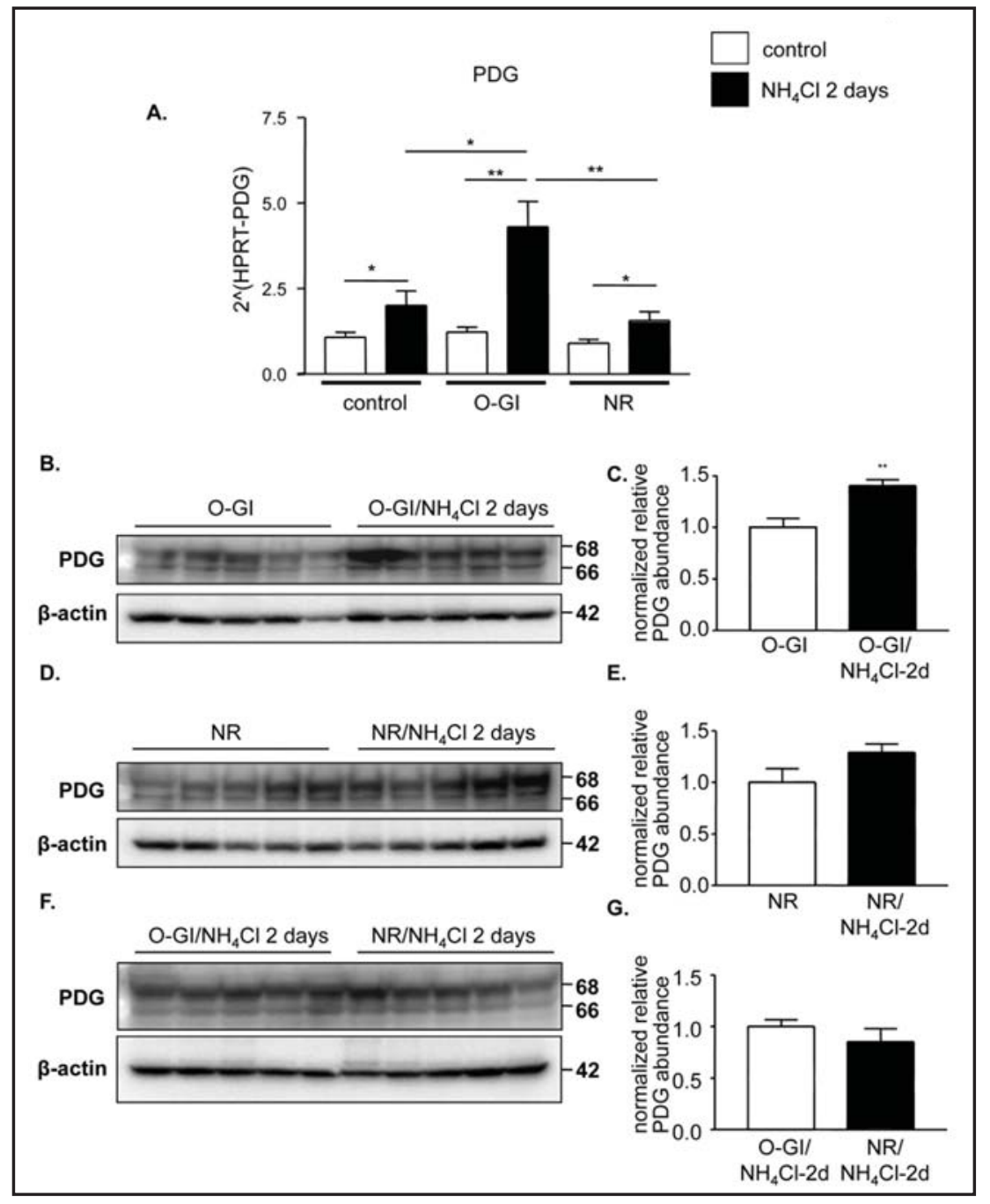

Thus, $\mathrm{NH}_{4} \mathrm{Cl}$ intake was higher in the lean group but comparable in the two obese groups. The similar intake of $\mathrm{NH}_{4} \mathrm{Cl}$ in the obese groups is also reflected by similar rates of urinary chloride excretion in these two groups. Moreover, dietary acid load from involatile acids was also similar between these two groups as indicated by similar rates of urinary sulfate and phosphate excretion (Table 1).

At baseline, there were no differences in urinary $\mathrm{pH}$ or ammonium excretion between groups. Differences were noted after the acid load was provided. Acid-loading resulted in significantly lower urinary $\mathrm{pH}$ in all groups in comparison to respective controls (Fig. 2A, Table 1). Although most clinical data show an acidic urine $\mathrm{pH}$ in patients with metabolic syndrome $[6,7,9]$, we observed a more alkaline urinary $\mathrm{pH}$ in $0-\mathrm{GI} / \mathrm{NH}_{4} \mathrm{Cl}$ treated mice than acid-loaded control mice fed a standard diet. Urinary electrolytes were analyzed to confirm the effect of acid-loading (Table 1). Urinary phosphate levels were unremarkable between groups, however $24 \mathrm{~h}$ phosphate excretion relative to urine volume showed reduced phosphate excretion in the 0-GI group compared to controls (Table 1). All acid-challenged mice had increased urinary ammonium excretion as expected, however, O-GI mice given $\mathrm{NH}_{4} \mathrm{Cl}$ had less ammonium excretion relative to urine volume (Fig. 2B, Table 1).

Dysregulation of SNAT3 and key ammoniagenic enzymes in obese, glucose-intolerant mice

We and others have previously shown that gene expression of SNAT3, and the key ammoniagenic enzymes PDG and PEPCK increases after inducing acidosis with $\mathrm{NH}_{4} \mathrm{Cl}$ 
Fig. 5. Phosphoenolpyruvate carboxykinase mRNA expression and protein abundance parallel PDG in cafeteria-fed mice. RNA was extracted from total kidney homogenates and mRNA expression was determined by semi-quantitative real-time RT-PCR. PEPCK mRNA expression was elevated in all acid-loaded groups, however both cafeteria fed groups showed the greatest increase in mRNA expression (A). (B-F) Cytosolic proteins were extracted from whole, non-perfused kidneys and probed for PEPCK. All blots were stripped and reprobed for $\beta$-actin to control for equal loading. Original blots are depicted with bar graphs summarizing normalized data. ${ }^{*} p<0.05,{ }^{* *} p<0.01$, ${ }^{* * *} p \leq 0.001$ between groups, $\mathrm{n}=5$ mice $/$ group.

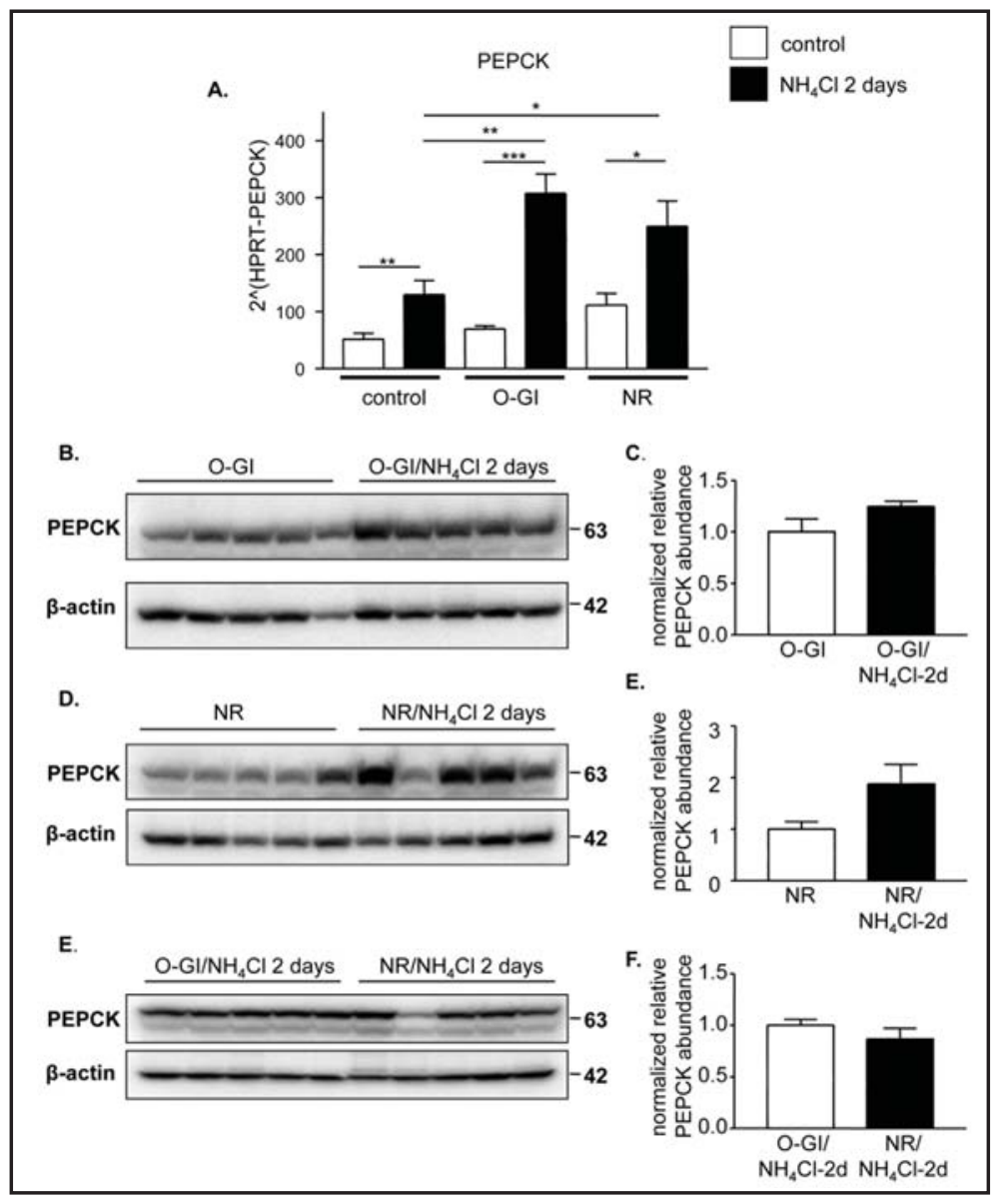

treatment [21, 22, 24, 25, 28, 37, 39, 75]. All acid-loaded groups showed enhanced SNAT3 mRNA and protein levels (Fig. 3A-K), however each group showed varying expression. 0-GI mice treated with $\mathrm{NH}_{4} \mathrm{Cl}$ had 2-fold higher SNAT3 mRNA abundance in comparison to controls given $\mathrm{NH}_{4} \mathrm{Cl}$ (Fig. $3 \mathrm{H}$ ). SNAT3 protein abundance was also 1.4-fold higher in 0-GI/ $\mathrm{NH}_{4} \mathrm{Cl}$ treated mice in comparison to $\mathrm{NR} / \mathrm{NH}_{4} \mathrm{Cl}$ treated mice (Fig. 3J) despite lower total $\mathrm{NH}_{4}^{+}$ excretion. Similarly, immunoblotting revealed elevated SNAT3 protein abundance in O-GI/ $\mathrm{NH}_{4} \mathrm{Cl}$ mice when compared to acid-loaded control mice (Fig. 3, H and I). PDG expression followed similar trends, with increased mRNA expression in all groups treated with $\mathrm{NH}_{4} \mathrm{Cl}$ (Fig. 4A). Acid-challenged obese mice (both 0 -GI and NR) showed relatively more PDG protein abundance than respective controls, similar to mRNA expression (Fig. 4, A-E). O-GI/ $\mathrm{NH}_{4} \mathrm{Cl}$ mice showed markedly elevated PDG mRNA abundance in comparison to $\mathrm{NR} / \mathrm{NH}_{4} \mathrm{Cl}$ mice, however no differences were detected on protein level (Fig. 4A, F-G). In parallel, PEPCK mRNA expression was markedly enhanced after an acid-load (2.5-fold) and in both obese groups (Fig. 5A); O-GI mice given $\mathrm{NH}_{4} \mathrm{Cl}$ showed the greatest fold change in mRNA expression (4.4-fold vs 2.2-fold; O-GI and NR groups, respectively). Protein abundance for PEPCK was also increased after an acid load, but similar to PDG, showed no differences among the two acid-loaded cafeteria fed groups (Fig. 5B-F).

In addition to potential alterations in renal ammoniagenesis, we sought to determine if there were any distal defects in ammonium transport in the kidney, in particular of the Rhesus glycoprotein, Rhcg, in our mice. Rhcg is largely expressed in the connecting tubule and the collecting duct, and plays an important role in apical ammonium extrusion into the final urine $[44,46,76]$. Rhcg mRNA expression was unremarkable between groups, however O-GI mice given an acute acid load showed increased Rhcg mRNA expression levels in comparison to O-GI treated without $\mathrm{NH}_{4} \mathrm{Cl}$ treatment (Fig. 6). 
Fig. 6. Normal expression of the ammonia transporter Rhcg. mRNA expression of Rhcg was determined in all groups. ${ }^{*} P \leq 0.05$ between groups.

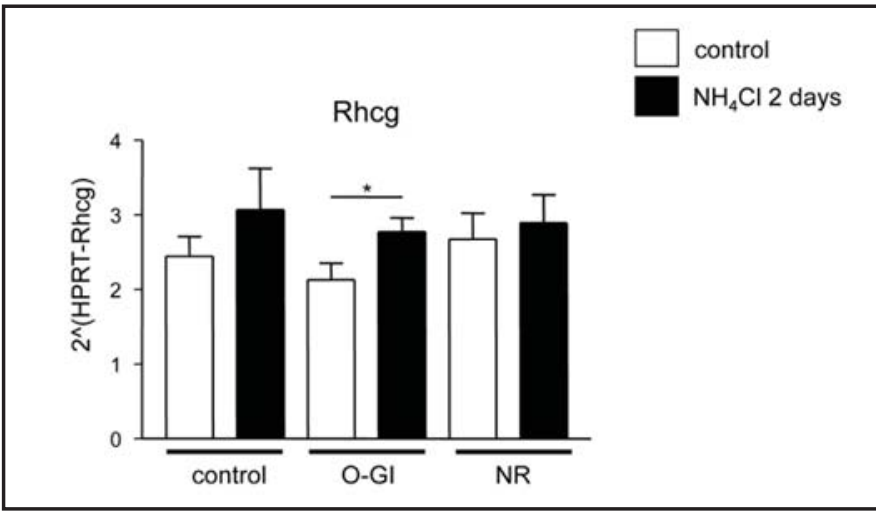

Fig. 7. Sodium/hydrogen exchanger activity is reduced in BBMV from acidloaded O-GI mice. BBMV preparations were made and acridine orange quenching experiments were performed. O-GI mice given an $\mathrm{NH}_{4} \mathrm{Cl}$ load had reduced NHE activity relative to respective controls. In contrast, acid-loaded NR mice showed enhanced NHE activity when compared with NR mice without $\mathrm{NH}_{4} \mathrm{Cl}$ treatment. ${ }^{*} P \leq 0.05$ and $* * * P \leq 0.001$ between groups.

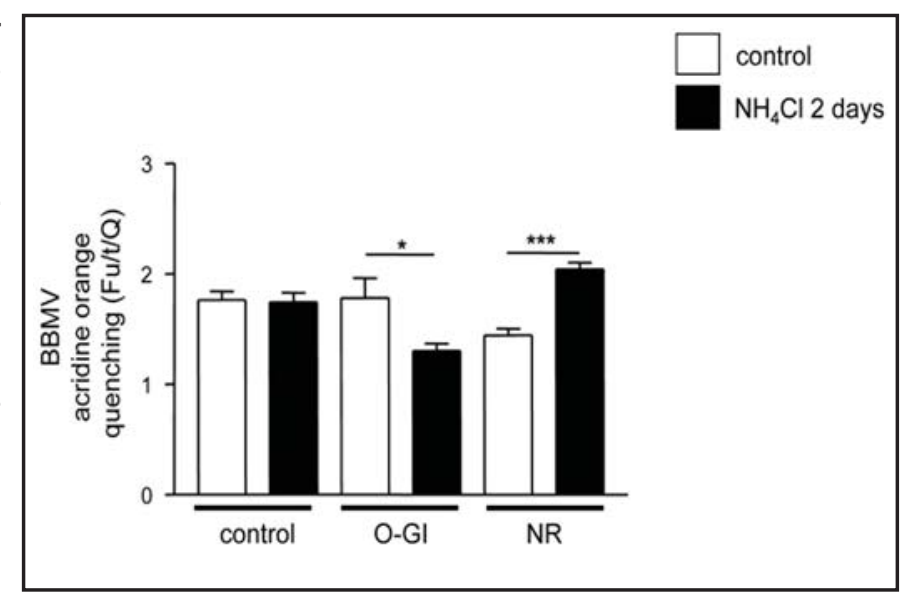

Brush border membrane sodium-proton exchanger activity is reduced in acid loaded obese, glucose-intolerant mice

To further identify mechanisms that could contribute to a reduction in urinary ammonium excretion, we examined the $\mathrm{Na}^{+} / \mathrm{H}^{+}$exchanger (NHE) activity in the brush border membrane of proximal tubules. Reduced NHE activity was observed in acid-loaded O-GI mice (Fig. 7).

\section{Discussion}

We created a mouse model of diet-induced obesity and glucose-intolerance to examine if changes in the regulation of the glutamine transporter, SNAT3, and enzymes involved in renal ammoniagenesis and gluconeogenesis, PDG and PEPCK could explain the urinary acidification and ammonium excretory defects seen in subjects with UAN and diabetes. After 10 weeks of dietary treatment, cafeteria-diet fed mice fell into two distinct cohorts based on body weight and response to IPGTT. O-IR mice were significantly obese and had severely elevated blood glucose, while NR mice were moderately obese with more normal blood glucose levels. Similar observations have been previously reported in rats [72-74, 77]. Since we used a highly inbred mouse strain (C57/BL6) with very little genetic variance in our study, the underlying reason for this difference remains unknown at present and provides an excellent model to study the impact of obesity related defects on the same genetic an dietary background. We show that challenging these obese, diabetic mice with an oral acid load leads to defective urinary ammonium excretion despite enhanced expression of key ammoniagenic proteins. O-GI mice exhibited strong upregulation of SNAT3, PDG and PEPCK mRNA and protein abundance suggesting enhanced ammoniagenesis. Moreover, the proximal tubular 


\section{Cellular Physiology and Biochemistry}

Cell Physiol Biochem 2014;34:575-589

\begin{tabular}{l|l}
\hline DOI: $10.1159 / 000363024$ & (C) 2014 S. Karger AG, Basel
\end{tabular}

www.karger.com/cpb

Busque/Stange/Wagner: Obesity and Dysregulation of SNAT3

brush border membrane sodium-proton exchanger activity was rather reduced in obese and glucose-intolerant mice whereas Rhcg mRNA expression appeared normal.

Studies by Abate et al. and Sakhaee et al. assessed whether or not insulin resistance is associated with UAN. Most patients with UAN had symptoms of metabolic syndrome and a low urinary $\mathrm{pH}$, but were without changes in urinary ammonium excretion. The ammonium concentration as a major component of net acid excretion, however, was significantly reduced in these subjects [7,15]. Our results show a slightly higher urinary $\mathrm{pH}$ and reduced urinary $\mathrm{NH}_{4}^{+}$excretion in $\mathrm{O}-\mathrm{GI}$ but not $\mathrm{NR}$ mice after an acid challenge, but not at baseline. This may be a species specific response to obesity and/or insulin resistance. However, it should also be noted that previous studies reporting decreased urinary $\mathrm{pH}$ in patients with metabolic syndrome sampled urine only over 4 to 12 hours $[7,11]$. In contrast, our samples were collected over $24 \mathrm{hrs}$ and the differences may thus reflect rather circadian rhythmicity of urine and acid excretion

However, challenging mice with an acute acid load unmasked several defects. O-IR mice showed slightly higher urinary $\mathrm{pH}$, in contrast with clinical data suggesting that patients with UAN and insulin resistance showed consistently low urinary $\mathrm{pH}$ values [6-10]. Despite lower $\mathrm{NH}_{4} \mathrm{Cl}$ intake in comparison to controls, both groups of obese mice displayed appropriate responses to acid-loading, namely reduced urinary $\mathrm{pH}$ and increased $\mathrm{NH}_{4}^{+}$excretion. Importantly, the difference seen between the glucose-tolerant and glucose-intolerant obese cannot be explained by differences in $\mathrm{NH}_{4} \mathrm{Cl}$ intake.

The renal manifestations of insulin resistance are not fully understood to date. Bobulescu et al. found that Zucker diabetic fatty rats exhibit reduced urinary ammonium excretion and $\mathrm{pH}$, as well as reduced NHE3 activity in the renal brush border membrane [63]. Interestingly, these rats showed an increase in renal triglyceride content, suggesting a lipotoxic effect of fatty acids in the kidney. In opossum kidney cell lines (OKP), as a model of the PT cell, administration of long-chain fatty acids produced a similar reduction in NHE3 activity, NHE3 membrane surface expression and ammonium excretion. Thus, accumulation of lipids, particularly free fatty acids (FFA) in the kidney may result in alterations in normal, physiological cellular processes, such as ammoniagenesis or gluconeogenesis. The etiological relationship between insulin resistance and low urinary $\mathrm{pH}$ has not been identified yet, but a major contribution of the proximal tubule is likely. O-GI mice showed strong upregulation of SNAT3, PDG and PEPCK on both protein and mRNA level, which would imply that ammoniagenesis and likely gluconeogenesis is being maximally fueled by the influx of glutamine into the PT cells.

Ammonium excretion by the proximal tubule involves $\mathrm{Na}^{+} / \mathrm{H}^{+}$-exchange activity in the brush border membrane, mainly mediated by the NHE3 isoform. The activity and expression of NHE3 has been linked to ammonium excretion even though in mouse models of NHE3 deficiency no clear defect in ammonium excretion has been reported to date [78]. NHE3 expression and activity in vivo and in the OKP cell line is stimulated by insulin [62]. We and Bobulescu et al. found that NHE3 expression or activity are altered in animal models of obesity and glucose intolerance pointing to a dysregulation of this important transporter [79].

The reduced urinary ammonium excretion may also more distal defects. mRNA expression levels of Rhcg, critical for renal ammonium excretion, however, did not show significant differences between groups. Urinary $\mathrm{pH}$ was only slightly more alkaline in 0-GI mice and is thus unlikely to account for a reduced driving force for $\mathrm{NH}_{3}$ secretion.

In summary, a diet-induced mouse model of obesity and glucose-intolerance demonstrates major changes in the regulation of enzymes and transporters involved in proximal tubular ammoniagenesis, gluconeogenesis, and ammonium excretion suggesting that obesity and insulin-resistance lead to a profound dysregulation of this important pathway in renal acid-base and glucose metabolism. 


\section{Cellular Physiology and Biochemistry}

Cell Physiol Biochem 2014;34:575-589

\begin{tabular}{l|l}
\hline DOI: $10.1159 / 000363024$ & (C) 2014 S. Karger AG, Basel
\end{tabular}

\section{Acknowledgements}

The use of the ZIRP Core Facility for Rodent Phenotyping is gratefully acknowledged. This study was supported by the Swiss National Science Foundation Grant 31003A-138143/1 to C.A. Wagner.

\section{References}

1 Wild S, Roglic G, Green A, Sicree R, King H: Global prevalence of diabetes: Estimates for the year 2000 and projections for 2030. Diabetes Care 2004;27:1047-1053.

2 Meydan N, Barutca S, Caliskan S, Camsari T: Urinary stone disease in diabetes mellitus. Scand J Urol Nephrol 2003;37:64-70.

-3 Stamatelou KK, Francis ME, Jones CA, Nyberg LM, Curhan GC: Time trends in reported prevalence of kidney stones in the united states: 1976-1994. Kidney Int 2003;63:1817-1823.

4 Taylor EN, Stampfer MJ, Curhan GC: Diabetes mellitus and the risk of nephrolithiasis. Kidney Int 2005;68:1230-1235.

5 Taylor JS, Kacmar JE, Nothnagle M, Lawrence RA: A systematic review of the literature associating breastfeeding with type 2 diabetes and gestational diabetes. J Am Coll Nutr 2005;24:320-326.

6 Asplin JR: Uric acid stones. Semin Nephrol 1996;16:412-424.

7 Sakhaee K, Adams-Huet B, Moe OW, Pak CY: Pathophysiologic basis for normouricosuric uric acid nephrolithiasis. Kidney international 2002;62:971-979.

8 Maalouf NM, Cameron MA, Moe OW, Sakhaee K: Novel insights into the pathogenesis of uric acid nephrolithiasis. Curr Opin Nephrol Hypertens 2004;13:181-189.

$>9$ Daudon M, Traxer O, Conort P, Lacour B, Jungers P: Type 2 diabetes increases the risk for uric acid stones. J Am Soc Nephrol 2006;17:2026-2033.

10 Daudon M, Lacour B, Jungers P: High prevalence of uric acid calculi in diabetic stone formers. Nephrol Dial Transplant 2005;20:468-469.

11 Kamel KS, Cheema-Dhadli S, Halperin ML: Studies on the pathophysiology of the low urine pH in patients with uric acid stones. Kidney Int 2002;61:988-994.

$>12$ Pak CY, Sakhaee K, Fuller C: Successful management of uric acid nephrolithiasis with potassium citrate. Kidney Int 1986;30:422-428.

13 Sakhaee K, Nicar M, Hill K, Pak CY: Contrasting effects of potassium citrate and sodium citrate therapies on urinary chemistries and crystallization of stone-forming salts. Kidney Int 1983;24:348-352.

$\checkmark 14$ Pak CY, Sakhaee K, Peterson RD, Poindexter JR, Frawley WH: Biochemical profile of idiopathic uric acid nephrolithiasis. Kidney Int 2001;60:757-761.

15 Abate N, Chandalia M, Cabo-Chan AV Jr, Moe OW, Sakhaee K: The metabolic syndrome and uric acid nephrolithiasis: Novel features of renal manifestation of insulin resistance. Kidney Int 2004;65:386-392.

-16 Henneman PH, Wallach S, Dempsey EF: The metabolism defect responsible for uric acid stone formation. J Clin Invest 1962;41:537-542.

17 Gutman AB, Yue TF: Urinary ammonium excretion in primary gout. J Clin Invest 1965;44:1474-1481.

18 Rapoport A, Crassweller PO, Husdan H, From GL, Zweig M, Johnson MD: The renal excretion of hydrogen ion in uric acid stone formers. Metabolism 1967;16:176-188.

19 Welbourne TC, Childress D, Givens G: Renal regulation of interorgan glutamine flow in metabolic acidosis. Am J Physiol 1986;251:R859-866.

20 Owen EE, Robinson RR: Amino acid extraction and ammonia metabolism by the human kidney during the prolonged administration of ammonium chloride. J Clin Invest 1963;42:263-276.

21 Karinch AM, Lin, C M, Wolfgang, C L, Pan, M, Souba, W W: Regulation of expression of the SN1 transporter during renal adaptation to chronic metabolic acidosis in rats. Am J Physiol Renal Physiol 2002;283:F10111019. 


\section{Cellular Physiology and Biochemistry}

Cell Physiol Biochem 2014;34:575-589

DOI: $10.1159 / 000363024$

(c) 2014 S. Karger AG, Basel

Published onIIne: August 11, 2014

www.karger.com/cpb

Busque/Stange/Wagner: Obesity and Dysregulation of SNAT3

22 Solbu TT, Boulland JL, Zahid W, Lyamouri Bredahl MK, Amiry-Moghaddam M, Storm-Mathisen J, Roberg BA, Chaudhry FA: Induction and targeting of the glutamine transporter SN1 to the basolateral membranes of cortical kidney tubule cells during chronic metabolic acidosis suggest a role in $\mathrm{pH}$ regulation. J Am Soc Nephrol 2005;16:869-877.

23 Karinch AM, Lin CM, Meng Q, Pan M, Souba WW: Glucocorticoids have a role in renal cortical expression of the snat3 glutamine transporter during chronic metabolic acidosis. Am J Physiol 2007;292:F448-455.

24 Moret C, Dave MH, Schulz N, Jiang JX, Verrey F, Wagner CA: Regulation of renal amino acid transporters during metabolic acidosis. Am J Physiol Renal Physiol 2007;292:F555-566.

25 Nowik M, Lecca MR, Velic A, Rehrauer H, Brandli AW, Wagner CA: Genome-wide gene expression profiling reveals renal genes regulated during metabolic acidosis. Physiol Genomics 2008;32:322-334.

26 Broer S: The SLC38 family of sodium-amino acid co-transporters. Pflugers Arch 2014;466:155-172.

27 McKinney TD, Davidson KK: Effect of potassium depletion and protein intake in vivo on renal tubular bicarbonate transport in vitro. Am J Physiol 1987;252:F509-516.

-28 Busque SM, Wagner CA: Potassium restriction, high protein intake, and metabolic acidosis increase expression of the glutamine transporter Snat3 (slc38a3) in mouse kidney. Am J Physiol Renal Physiol 2009;297:F440-450.

29 Tannen RL: Relationship of renal ammonia production and potassium homeostasis. Kidney Int 1977;11:453-465.

-30 Sastrasinh S, Sastrasinh M: Renal mitochondrial glutamine metabolism during $\mathrm{K}^{+}$depletion. Am J Physiol 1986;250:F667-673.

-31 Nonoguchi H, Takehara Y, Endou H: Intra- and inter-nephron heterogeneity of ammoniagenesis in rats: Effects of chronic metabolic acidosis and potassium depletion. Pflugers Arch 1986;407:245-251.

-32 Nagami GT: Effect of bath and luminal potassium concentration on ammonia production and secretion by mouse proximal tubules perfused in vitro. J Clin Invest 1990;86:32-39.

-33 Jaeger P, Karlmark B, Giebisch G: Ammonium transport in rat cortical tubule: Relationship to potassium metabolism. Am J Physiol 1983;245:F593-600.

-34 Bounoure L, Ruffoni D, Muller R, Kuhn GA, Bourgeois S, Devuyst O, Wagner CA: The role of the renal ammonia transporter rhcg in metabolic responses to dietary protein. J Am Soc Nephrol 2014

-35 Tong J, Harrison G, Curthoys NP: The effect of metabolic acidosis on the synthesis and turnover of rat renal phosphate-dependent glutaminase. Biochem J 1986;233:139-144.

-36 Iynedjian PB, Ballard FJ, Hanson RW: The regulation of phosphoenolpyruvate carboxykinase (gtp) synthesis in rat kidney cortex. The role of acid-base balance and glucocorticoids. J Biol Chem 1975;250:5596-5603.

-37 Hwang JJ, Curthoys NP: Effect of acute alterations in acid-base balance on rat renal glutaminase and phosphoenolpyruvate carboxykinase gene expression. J Biol Chem 1991;266:9392-9396.

-38 Cimbala MA, Lamers WH, Nelson K, Monahan JE, Yoo-Warren H, Hanson RW: Rapid changes in the concentration of phosphoenolpyruvate carboxykinase mRNA in rat liver and kidney. Effects of insulin and cyclic AMP. J Biol Chem 1982;257:7629-7636.

-39 Curthoys NP, Gstraunthaler G: Mechanism of increased renal gene expression during metabolic acidosis. Am J Physio 2001;281:F381-390.

40 Laghmani K, Preisig, P A, Moe, O W, Yanagisawa, M, Alpern, R J: Endothelin-1/endothelin-B receptormediated increases in NHE3 activity in chronic metabolic acidosis. J Clin Invest 2001;107:1563-1569.

-41 Ambuhl PM, Amemiya, M, Danczkay, M, Lotscher, M, Kaissling, B, Moe, O W, Preisig, P A, Alpern, R J: Chronic metabolic acidosis increases NHE3 protein abundance in rat kidney. Am J Physiol 1996;271:F917-925.

-42 Wu MS, Biemesderfer D, Giebisch G, Aronson PS: Role of NHE3 in mediating renal brush border Na+-H+ exchange. Adaptation to metabolic acidosis. J Biol Chem 1996;271:32749-32752.

-43 Attmane-Elakeb A, Mount, D B, Sibella, V, Vernimmen, C, Hebert, S C, Bichara, M: Stimulation by in vivo and in vitro metabolic acidosis of expression of rBSC-1, the $\mathrm{Na}^{+}-\mathrm{K}^{+}\left(\mathrm{NH}_{4}{ }^{+}\right)-2 \mathrm{Cl}$ cotransporter of the rat medullary thick ascending limb. J Biol Chem 1998;273:33681-33691.

44 Bourgeois S, Bounoure L, Christensen EI, Ramakrishnan SK, Houillier P, Devuyst O, Wagner CA: Haploinsufficiency of the ammonia transporter rhcg predisposes to chronic acidosis: Rhcg is critical for apical and basolateral ammonia transport in the mouse collecting duct. J Biol Chem 2013;288:5518-5529. 


\section{Cellular Physiology and Biochemistry}

Cell Physiol Biochem 2014;34:575-589

\begin{tabular}{l|l}
\hline DOI: $10.1159 / 000363024$ & (c) 2014 S. Karger AG, Basel
\end{tabular}

Busque/Stange/Wagner: Obesity and Dysregulation of SNAT3

45 Stettner P, Bourgeois S, Marsching C, Traykova-Brauch M, Porubsky S, Nordstrom V, Hopf C, Koesters R, Sandhoff R, Wiegandt H, Wagner CA, Grone HJ, Jennemann R: Sulfatides are required for renal adaptation to chronic metabolic acidosis. Proc Natl Acad Sci U S A 2013;110:9998-10003.

46 Biver S, Belge H, Bourgeois S, Van Vooren P, Nowik M, Scohy S, Houillier P, Szpirer J, Szpirer C, Wagner CA, Devuyst 0, Marini AM: A role for rhesus factor Rhcg in renal ammonium excretion and male fertility. Nature 2008;456:339-343.

-47 Weiner ID, Verlander JW: Role of $\mathrm{NH}_{3}$ and $\mathrm{NH}_{4}{ }^{+}$transporters in renal acid-base transport. Am J Physiol Renal Physiol 2011;300:F11-23.

48 Sahai A, Nissim I, Sandler RS, Tannen RL: Prostaglandin F2 alpha- and 12-o-tetradecanoylphorbol-13acetate-induced alterations in the pathways of renal ammoniagenesis. J Am Soc Nephrol 1995;5:17921798.

49 Chobanian MC, Hammerman MR: Insulin stimulates ammoniagenesis in canine renal proximal tubular segments. Am J Physiol 1987;253:F1171-1177.

50 Chobanian MC, Julin CM: Angiotensin II stimulates ammoniagenesis in canine renal proximal tubule segments. Am J Physiol 1991;260:F19-26.

51 Guder WG, Schmidt U: The localization of gluconeogenesis in rat nephron. Determination of phosphoenolpyruvate carboxykinase in microdissected tubules. Hoppe Seylers Z Physiol Chem 1974;355:273-278.

52 Gullans SR, Brazy PC, Dennis VW, Mandel LJ: Interactions between gluconeogenesis and sodium transport in rabbit proximal tubule. Am J Physiol 1984;246:F859-869.

53 Vinay P, Gougoux A, Lemieux G: Isolation of a pure suspension of rat proximal tubules. Am J Physiol 1981;241:F403-411.

54 Rogers S, Gavin JR, 3rd, Hammerman MR: Phorbol esters inhibit gluconeogenesis in canine renal proximal tubular segments. Am J Physiol 1985;249:F256-262.

55 Burch HB, Narins RG, Chu C, Fagioli S, Choi S, McCarthy W, Lowry OH: Distribution along the rat nephron of three enzymes of gluconeogenesis in acidosis and starvation. Am J Physiol 1978;235:F246-253.

-56 Kida K, Nakajo S, Kamiya F, Toyama Y, Nishio T, Nakagawa H: Renal net glucose release in vivo and its contribution to blood glucose in rats. J Clin Invest 1978;62:721-726.

57 Joseph PK, Subrahmanyam K: Effect of growth hormone, insulin, thyroxine and cortisone on renal gluconeogenesis. Arch Biochem Biophys 1968;127:288-291.

-58 Lupianez JA, Dileepan KN, Wagle SR: Interrelationship of somatostatin, insulin, and calcium in the control of gluconeogenesis in kidney cortex slices. Biochim Biophys Res Comm 1979;90:1153-1158.

59 Sechi LA: Mechanisms of insulin resistance in rat models of hypertension and their relationships with salt sensitivity. J Hypertens 1999;17:1229-1237.

-60 DeFronzo RA, Cooke CR, Andres R, Faloona GR, Davis PJ: The effect of insulin on renal handling of sodium, potassium, calcium, and phosphate in man. J Clin Invest 1975;55:845-855.

61 Gesek FA, Schoolwerth AC: Insulin increases $\mathrm{Na}^{+}-\mathrm{H}+$ exchange activity in proximal tubules from normotensive and hypertensive rats. Am J Physiol 1991;260:F695-703.

62 Klisic J, Hu MC, Nief V, Reyes L, Fuster D, Moe OW, Ambuhl PM: Insulin activates $\mathrm{Na}^{+} / \mathrm{H}^{+}$exchanger 3: Biphasic response and glucocorticoid dependence. Am J Physiol 2002;283:F532-539.

63 Bobulescu IA, Dubree M, Zhang J, McLeroy P, Moe OW: Effect of renal lipid accumulation on proximal tubule $\mathrm{Na}^{+} / \mathrm{H}^{+}$exchange and ammonium secretion. Am J Physiol Renal Physiol 2008;294:F1315-1322.

64 Sclafani A, Springer D: Dietary obesity in adult rats: Similarities to hypothalamic and human obesity syndromes. Physiol \& Behav 1976;17:461-471.

65 Berthelot M: Violet d'aniline. Rep Chim App 1859;1:284.

-66 Slot C: Plasma creatinine determination. A new and specific jaffe reaction method. Scand J Clin Lab Invest 1965;17:381-387.

-67 Sundberg BE, Waag E, Jacobsson JA, Stephansson O, Rumaks J, Svirskis S, Alsio J, Roman E, Ebendal T, Klusa $\mathrm{V}$, Fredriksson R: The evolutionary history and tissue mapping of amino acid transporters belonging to solute carrier families slc32, slc36, and slc38. J Mol Neurosci 2008;35:179-193.

-68 Curi TC, De Melo MP, De Azevedo RB, Zorn TM, Curi R: Glutamine utilization by rat neutrophils: Presence of phosphate-dependent glutaminase. Am J Physiol 1997;273:C1124-1129. 


\section{Cellular Physiology $\quad$ Cell Physiol Biochem 2014;34:575-589 and Biochemistry

69 Curthoys NP, Kuhlenschmidt T, Godfrey SS, Weiss RF: Phosphate-dependent glutaminase from rat kidney. Cause of increased activity in response to acidosis and identity with glutaminase from other tissues. Archiv Biochem Biophys 1976;172:162-167.

70 Biber J, Stieger B, Stange G, Murer H: Isolation of renal proximal tubular brush-border membranes. Nat Protoc 2007;2:1356-1359.

-71 Honegger KJ, Capuano P, Winter C, Bacic D, Stange G, Wagner CA, Biber J, Murer H, Hernando N: Regulation of sodium-proton exchanger isoform 3 (NHE3) by PKA and exchange protein directly activated by cAMP (EPAC). Proc Nat Acad Sci USA 2006;103:803-808.

72 Levin BE, Finnegan M, Triscari J, Sullivan AC: Brown adipose and metabolic features of chronic dietinduced obesity. Am J Physiol 1985;248:R717-723.

73 Levin BE, Hogan S, Sullivan AC: Initiation and perpetuation of obesity and obesity resistance in rats. Am J Physiol 1989;256:R766-771.

74 Levin BE, Triscari J, Hogan S, Sullivan AC: Resistance to diet-induced obesity: Food intake, pancreatic sympathetic tone, and insulin. Am J Physiol 1987;252:R471-478.

75 Curthoys NP, Lowry OH: The distribution of glutaminase isoenzymes in the various structures of the nephron in normal, acidotic, and alkalotic rat kidney. J Biol Chem 1973;248:162-168.

-76 Verlander JW, Miller RT, Frank AE, Royaux IE, Kim YH, Weiner ID: Localization of the ammonium transporter proteins Rhbg and Rhcg in mouse kidney. Am J Physiol 2003;284:F323-337.

-77 Levin BE, Keesey RE: Defense of differing body weight set points in diet-induced obese and resistant rats. Am J Physiol 1998;274:R412-419.

-78 Li HC, Du Z, Barone S, Rubera I, McDonough AA, Tauc M, Zahedi K, Wang T, Soleimani M: Proximal tubule specific knockout of the $\mathrm{Na}^{+} / \mathrm{H}^{+}$exchanger NHE3: Effects on bicarbonate absorption and ammonium excretion. J Mol Med (Berl) 2013;91:951-963.

79 Bobulescu IA, Dubree M, Zhang J, McLeroy P, Moe OW: Reduction of renal triglyceride accumulation: Effects on proximal tubule $\mathrm{Na}^{+} / \mathrm{H}^{+}$exchange and urinary acidification. Am J Physiol Renal Physiol 2009;297:F1419-1426. 